\title{
Resistance in Capsicum spp. to anthracnose affected by different stages of fruit development during pre- and post- harvest
}

\author{
Soraia A. M. Silva ${ }^{1}$, Rosana Rodrigues ${ }^{1}$, Leandro S.A. Gonçalves ${ }^{2}$, Cláudia P. Sudré ${ }^{1}$, Cíntia S. Bento ${ }^{1}$, \\ Margarida G. F. Carmo ${ }^{3}$ \& Artur M. Medeiros ${ }^{1}$
}

${ }^{1}$ Laboratório de Melhoramento Genético Vegetal, Universidade Estadual do Norte Fluminense Darcy Ribeiro, Campos dos Goytacazes, Rio de Janeiro 28013-602, Brazil; ${ }^{2}$ Departamento de Agronomia, Universidade Estadual de Londrina, Londrina, Paraná 86051-990, Brazil. ${ }^{3}$ Departamento de Fitotecnia, Universidade Federal Rural do Rio de Janeiro, Seropédica, RJ, Brazil

Author for correspondence: Rosana Rodrigues, e-mail: rosana@uenf.br

\begin{abstract}
This study aimed to investigate the reaction of unripe and ripe fruits of Capsicum spp. accessions to Colletotrichum gloeosporioides during the pre- and post-harvest periods, and to identify sources of resistance for use in plant breeding programs. Thirty-seven Capsicum spp. accessions of the Universidade Estadual do Norte Fluminense Darcy Ribeiro were evaluated. They were cultivated in a greenhouse and arranged in a completely randomized design with five replications. Twenty fruits from each accession were inoculated at two stages (unripe and ripe) in two different environments (fruits inoculated in the plant and detached fruit inoculated under laboratory conditions). The symptoms were assessed every 24 hours between the 1 st and 8 th days after inoculation. There were highly significant differences in the values of the area under the disease progress curve and in severity, considering all sources of individual variation and their interactions. Values of low and moderate correlation were observed for inoculation of unripe and ripe fruit in both environments. These results indicate the existence of distinct genes responsible for resistance at different stages of fruit development. Complete lack of symptoms was registered only for accessions UENF 1718 and UENF 1797 (C. baccatum var. pendulum).
\end{abstract}

Key words: Colletotrichum gloeosporioides, chili pepper, plant breeding, plant disease.

Anthracnose causes extensive losses in plants of the genus Capsicum before and after harvest, especially in hot and humid climates (Pereira et al., 2011; Park et al., 2012). The disease is considered of complex etiology since it can be caused by different species of Colletotrichum, including C. acutatum J.H. Simmonds, C. capsici (Syd.) E. J. Butler \& Bisby, C. coccodes (Wallr.) S. Hughes and C. gloeosporioides Penz (Than et al., 2008a; Mahasuk et al., 2009b; Mongkolporn et al., 2010; Park et al., 2012). These species cause disease in different organs of Capsicum plants. For example, C. acutatum and C. gloeosporioides infect pepper fruits at all stages of development, but they generally do not infect leaves or stems, which in turn are infected by C. coccodes (Kim et al., 2004). Depressed circular or angular lesions, with concentric rings of moist acervuli that produce masses of pink or orange conidia are typical symptoms in fruit (Than et al., 2008b).

Although many strategies are proposed to control anthracnose in Capsicum, such as the use of pathogen-free seeds, crop rotation with non-host species, elimination of alternative hosts and crop debris, chemical fungicide application, and biological control, the use of resistant cultivars is considered the most effective control method
(Than et al., 2008b; Park et al., 2012), since it not only reduces losses, but also prevents costs with the use of chemicals and labor in disease control (Agrios, 2005).

Several breeding programs have been developed aimed at identifying and incorporating resistance genes in cultivars of sweet and chili pepper (Pakdeevaraporn et al., 2005; Yoon \& Park 2005; Kim et al., 2008; Pereira et al., 2011). Sources of resistance have been identified in pepper accessions, including accession PBC932 in Capsicum chinense, resistant to Colletotrichum capsici, and Capsicum baccatum resistant to Colletotrichum gloeosporioides (Babu et al., 2011). Knowledge of inheritance of resistance to anthracnose in Capsicum is essential for the success of breeding programs, because it helps breeders to select the best breeding methods for obtaining resistant cultivars.

However, resistance inheritance may vary according to Colletotrichum. For example, there are reports indicating that resistance to $C$. capsici is controlled by a dominant gene (Lin et al., 2002), and to C. dematium by a partially dominant gene (Park et al., 1990b). For resistance to $C$. gloeosporioides, inheritance was described as overdominant or partially dominant (Park et al., 1990a). The presence of a recessive gene controlling anthracnose resistance has also 
been described in Capsicum chinense (Pakdeevaraporn et al., 2005). Voorrips et al. (2004) used quantitative trait loci (QTL) mapping and identified a highly significant main QTL with major effect on three evaluated traits (frequency of infection, lesion true diameter and overall diameter of lesion) after the inoculation of $C$. gloeosporioides in plants from crosses between Capsicum annuиm and C. chinense. In this study, tests to assess resistance were performed only in ripe fruit.

Pathogenicity studies showed different reactions when the same isolate was inoculated into ripe and unripe fruits of a pepper genotype (Kim et al., 1999; Than et al., 2008b). Some Colletotrichum isolates were pathogenic to unripe fruit of resistant genotypes 'PBC932' (C. chinense), 'PBC80' and 'PBC81' (C. baccatum), but they were not pathogenic to red fruit of those genotypes, which suggests that different resistance genes are expressed at different stages of fruit maturity (Taylor et al., 2007). A similar result was observed by Mahasuk et al. (2009a), who studied the inheritance of resistance to $C$. capsici at different stages of fruit ripening (unripe and ripe) from crosses between Capsicum annuum (susceptible) and Capsicum chinense (resistant). They verified the involvement of two different genes responsible for resistance in ripe and unripe fruit, suggesting that the change in fruit maturation may have triggered the expression of different genes at different stages.

The present study aimed to investigate the reaction of unripe and ripe fruit from accessions of Capsicum spp. to Colletotrichum gloeosporioides (Penz.) during the preand post-harvest season, and to identify possible sources of resistance for use in plant breeding programs.

Thirty-seven accessions of Capsicum spp. from the germplasm collection of the Universidade Estadual do Norte Fluminense Darcy Ribeiro (UENF) were assessed. These accessions were previously characterized by Sudré et al. (2005) and Bento et al. (2007) according to morphological and agronomic descriptors; and by Bento et al. (2009), for resistance to Pepper yellow mosaic virus (PepYMV; genus Potyvirus, family Potyviridae). The accessions were sown in trays of 128 cells with organic-vegetable substrate. After the emergence of two pairs of true leaves, the seedlings were individually transferred to plastic pots containing a mixture of soil and substrate (2:1 ratio) and grown in a greenhouse at UENF, located in Campos dos Goytacazes, Rio de Janeiro, Brazil. The practices recommended for the crop were carried out and the plants were arranged in a completely randomized design with five replications.

An isolate of C. gloeosporioides obtained from sweet pepper (isolated in 1984 and identified by code MMBF 04/84) was donated by Dr. Christiane C. Aparecido from the "Mario Barreto Figueiredo" fungal collection at Instituto Biológico, São Paulo, Brazil. The isolate was previously tested in fruit from the accession UENF 1616 (C. baccatum var. pendulum) for confirmation of virulence. For inoculum preparation, the isolate was grown on PDA medium, $\mathrm{pH}$
7.0 and incubated in the dark at $25^{\circ} \mathrm{C}$ until the formation of colonies (between seven and ten days). The spore suspension was prepared minutes before each inoculation at a concentration of $1 \times 10^{6}$ conidia $/ \mathrm{mL}$, adjusted by counting in a Neubauer chamber. The releasing of conidia in water was done with the aid of a fine brush.

Twenty fruit of each accession were inoculated at two developmental stages (unripe and ripe). The unripe and ripe fruit were inoculated in two different environments, which resulted in four combinations: unripe fruit inoculated in the plant (UFP); unripe fruit detached and inoculated under laboratory conditions (UFL); ripe fruit inoculated in the plant (RFP); and ripe fruit detached and inoculated under laboratory conditions (RFL). In fruit inoculated and maintained in the plant, the inoculation was carried out with the aid of micropipettes; $20 \mu \mathrm{L}$ of the conidia suspension were inoculated in the pericarp, in the center of the fruit. Fruit harvested and transported to the laboratory for inoculation were sterilized with $1 \%(\mathrm{w} / \mathrm{v})$ sodium hypochlorite for 5 min and washed three times in sterile deionized water. The fruits were drilled in the pericarp central region using a micropipette tip before inoculation and were incubated at $28^{\circ} \mathrm{C}$ in the dark and $100 \% \mathrm{RH}$ for $24 \mathrm{~h}$ and then under a $12 / 12$ light/dark cycle with 70-80\% RH.

Severity of anthracnose on fruit was evaluated every 24 hours, between the 1st and 8th days after inoculation, by the adapted scale proposed by Montri et al. (2009), where 1 means highly resistant; 3 , resistant; 4 , moderately resistant; 6 , moderately susceptible; 8 , susceptible; and 10 , highly susceptible. The data of severity from periodic observations were used to calculate the area under the disease progress curve (AUDPC), according to Campbell \& Madden (1990). The data were submitted to the Shapiro-Wilk test for normality, and the absence of data normality was observed. Therefore, the data were subjected to nonparametric Kruskal-Wallis test and subsequently ranked by the Steel test. The Spearman correlation between the values obtained for AUDPC and the scores attributed to the evaluation was also conducted. All analyses were performed using the R program (www.r-project.org).

There was a highly significant difference $(P<0.01)$ for values of AUDPC and scores attributed to severity of anthracnose, considering all sources of individual variation: unripe fruit in the plant (UFP); unripe detached fruit (UFL); ripe fruit in the plant (RFP) and ripe detached fruit (RFL) (Table 1). This indicates variation for AUDPC and severity at the stages of fruit evaluation (unripe and ripe) and in the tested environments (fruit in the plant in greenhouse and fruit detached from plant and inoculated in the laboratory). Thus, it is possible to select resistant accessions under different inoculation conditions. Regarding interactions between fruit evaluated in different environments (greenhouse and laboratory), and between fruit at different maturation stages, significance was also observed for all combinations. The fruits detached and evaluated in the laboratory obtained the highest values for the variables AUDPC and severity, 
Resistance in Capsicum spp. to anthracnose affected by different stages of fruit...

TABLE 1 - Non-parametric analysis for the effects of inoculation of Colletotrichum gloeosporioides in fruit from 37 accessions of Capsicum spp., at different stages, inoculated in the plant and fruit detached and inoculated under laboratory conditions: Kruskal-Wallis test for to the area under the disease progress curve (AUDPC) and scores given to anthracnose symptoms.

\begin{tabular}{lccc}
\hline \hline Sources of variation & Degree of freedom & \multicolumn{2}{c}{ Chi-square } \\
\cline { 3 - 4 } & & Posts of AUDPC & Posts of Scores \\
\hline Unripe fruit on plant (UFP) & 36 & $95.64(P<0.001)$ & $92.44(P<0.001)$ \\
Unripe detached fruit (UFL) & 36 & $95.89(P<0.001)$ & $97.31(P<0.001)$ \\
Ripe fruit on plant (RFP) & 36 & $84.44(P<0.001)$ & $86.52(P<0.001)$ \\
Ripe detached fruit (RFL) & 36 & $88.82(P<0.001)$ & $93.58(P<0.001)$ \\
UFP x UFL & 1 & $04.49(P<0.034)$ & $08.07(P<0.004)$ \\
RFP x RFL & 1 & $05.47(P<0.019)$ & $11.41(P<0.001)$ \\
UFP x RFP & 1 & $07.29(P<0.007)$ & $05.37(P<0.021)$ \\
UFL x RFL & 1 & $06.68(P<0.009)$ & $04.06(P<0.044)$ \\
\hline
\end{tabular}

compared to fruit evaluated in a greenhouse. This result is mainly due to environmental conditions to which fruit were submitted after inoculation, considering that the detached fruit were submitted to ideal conditions of temperature and humidity for the development of the disease, while these conditions were not always met in greenhouse.

The test performed under laboratory conditions allowed for better discrimination of resistant accessions (no symptoms) compared to the susceptible ones, both in unripe and ripe fruit, compared to the accessions assessed in the field (Figures 1 and 2). The number of accessions that did not express symptoms in ripe fruit either in the plant or in the laboratory was lower, compared to unripe fruit. Ten accessions of unripe fruit showed no symptoms, from which eight were accessions of $C$. baccatum var. pendulum (UENF 1624, UENF 1628, UENF 1714, UENF 1718, UENF 1732, UENF 1733 and UENF 1737) and two, of C. chinense (UENF 1764 and UENF 1770). Among these resistant accessions of C. baccatum var. pendulum, accessions UENF 1624, UENF 1732, UENF 1764 and UENF 1770 were also considered resistant to PepYMV by Bento et al. (2009). Regarding the ripe fruit, only six accessions did not develop symptoms, four of which were C. chinense accessions (UENF 1554, UENF 1703, UENF 1706 and UENF 1751).

The absence of symptoms throughout the experimental evaluation period was only recorded for two accessions, UENF 1718 and UENF 1797, both belonging to $C$. baccatum var. pendulum which were promising for resistance. Kanchana-Udomkan et al. (2004) found that fruit size does not affect the development of the disease, and unripe fruit of $C$. chinense were more susceptible to anthracnose caused by $C$. gloeosporioides than ripe fruit. Pakdeevaraporn et al. (2005) and Mahasuk et al. (2009a) showed that different genes control resistance to anthracnose in unripe and ripe fruit, which is extremely significant for Capsicum breeding seeking resistance to anthracnose. Mongkolporn et al. (2010) also observed different reactions caused by the stage of development of Capsicum spp. fruit inoculated with different species of Colletotrichum.
The low to moderate correlation values observed in the results of inoculation of unripe and ripe fruit in greenhouse or laboratory (Table 2) also indicate the existence of distinct genes responsible for resistance at different stages of fruit development. This fact brings more difficulties to breeders at the stages of identification and transfer of resistance genes to obtain improved cultivars, since it will require tests to be performed at different stages of fruit development. High correlation (above 0.87 ) was observed between scores and AUDPC, which indicates that the selection based on any of these variables will be almost the same. The correlation between assessments in detached and non-detached fruit was moderate (unripe - AUDPC: 0.62 and score: 0.59; and ripe - AUDPC: 0.77 and score: 0.79 ). This demonstrates the influence of environmental conditions on disease severity in some of the accessions evaluated.

A significant difference was observed for AUDPC and a highly significant difference was observed for the score when the expression of symptoms was considered in unripe fruit, for assessments carried out both in the plants and in laboratory, which reveals interaction between the stage of fruit development and the environment where the evaluation was carried out. The same pattern of results was observed for fruit assessed at the ripe stage. However, a highly significant difference and a significant difference were observed, respectively, for AUDPC and for score, when unripe and ripe fruit were compared, for fruit evaluated in the plant and in the laboratory (Figures 1 and 2).

The minimum value observed for AUDPC in four combinations tested was 8.00 , due to note 1 corresponding to no symptoms and an eight-day evaluation period, while the maximum value recorded was 62.67 for accession UENF 1750, when its fruit were inoculated in the laboratory. Comparison between the results obtained from the unripe and ripe fruit reveal that the highest values for AUDPC and scores were obtained for ripe fruit. Kim et al. (1999) evaluated different responses of the C. gloeosporioides isolate ' $\mathrm{KG}$ 13 ' in unripe and ripe fruit of $C$. annuum and verified a differential reaction of the isolate at different stages of fruit ripening. This result was attributed to physical and chemical 


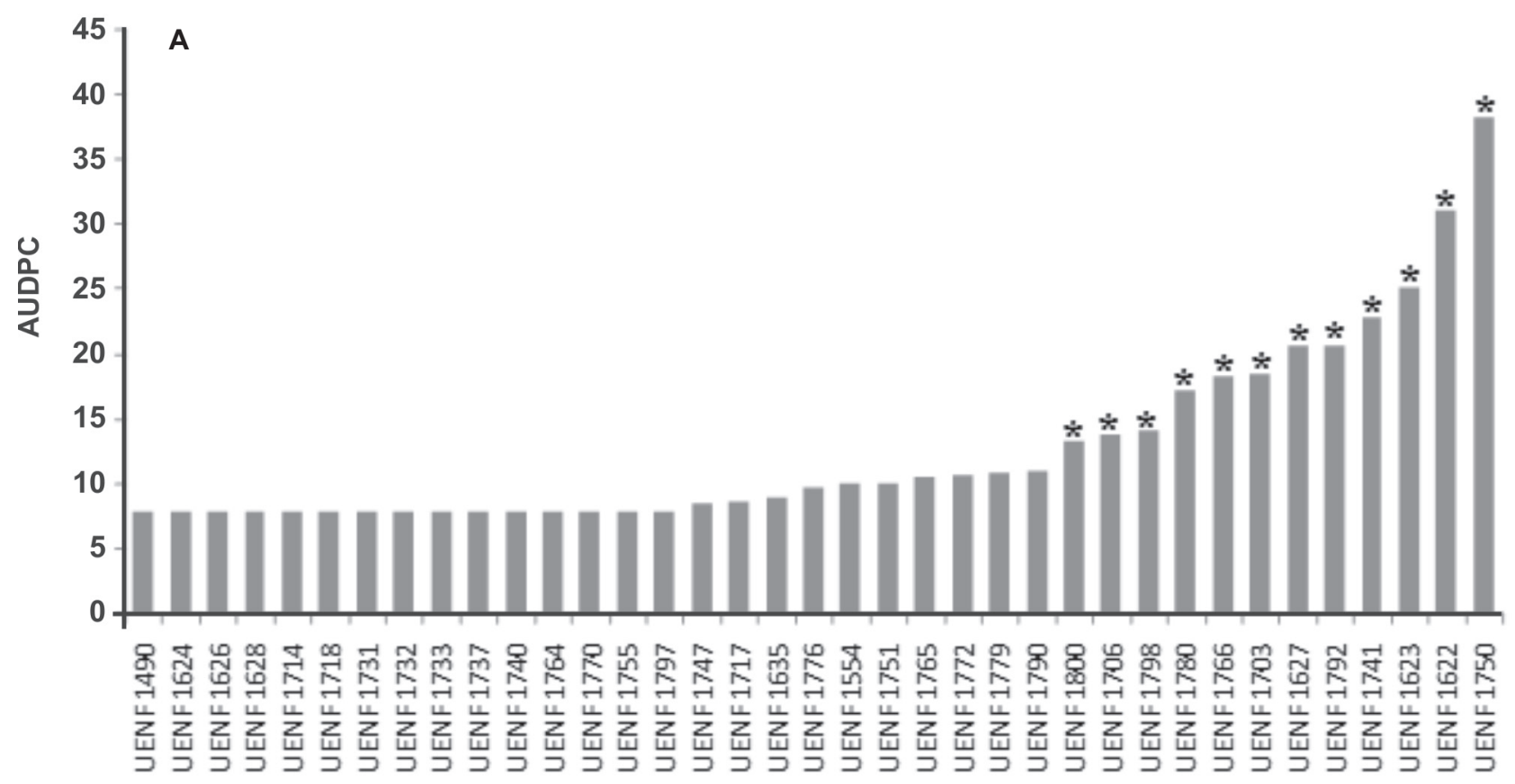

\section{Genotypes}

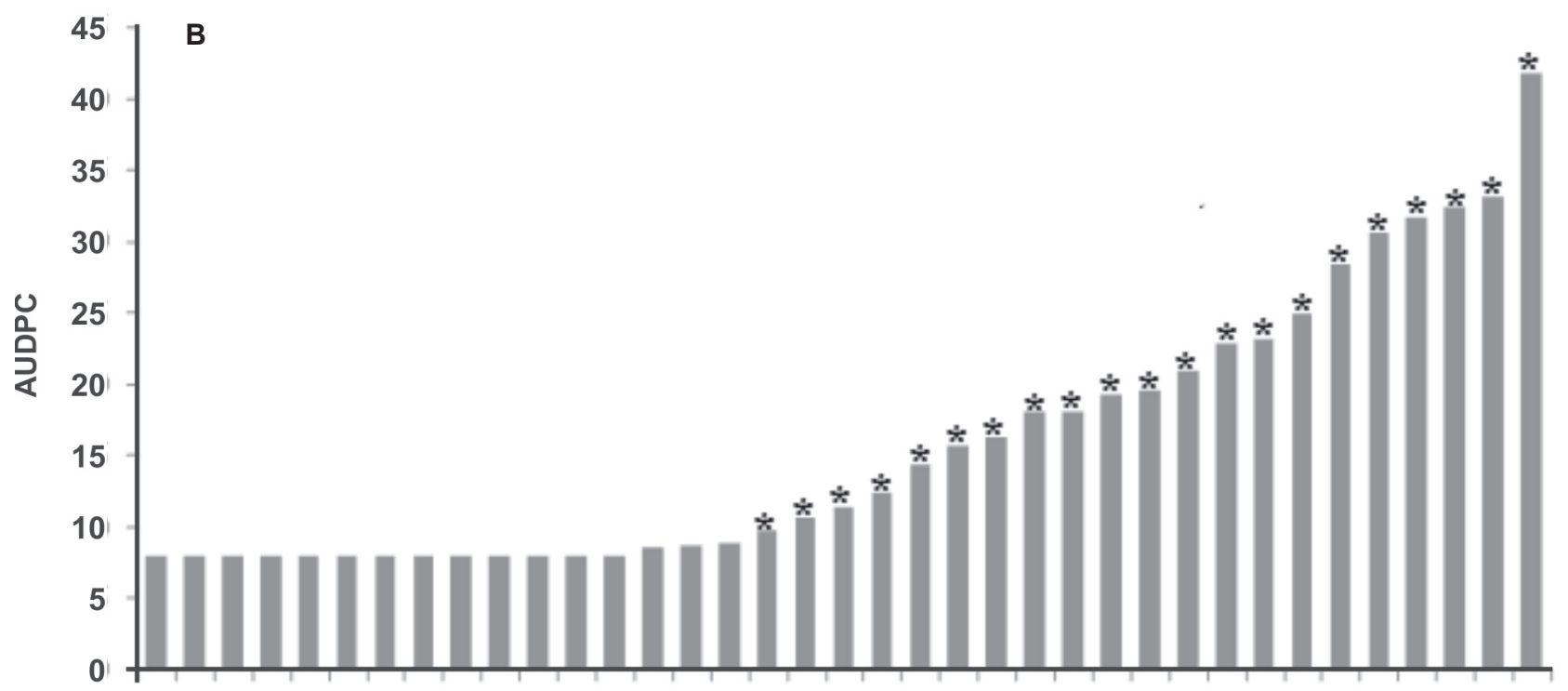

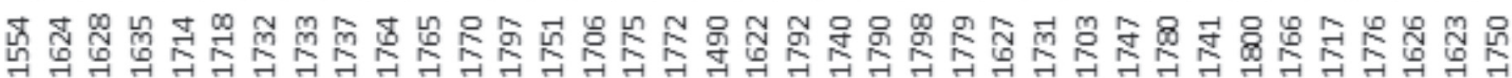

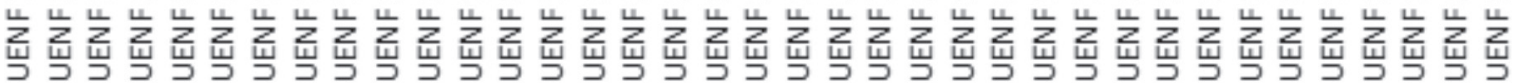

\section{Genotypes}

FIGURE 1 - Average values observed for the area under the disease progress curve (AUDPC) in unripe fruit in the plant (A) and detached (B) from 37 accessions of Capsicum spp. inoculated with Colletotrichum gloeosporioides. *, Significant differences of the accessions with no symptoms, in relation to the other accessions, at $5 \%$ probability by the Steel test.

differences in cuticular layers of fruit. However, these authors observed more severe symptoms in unripe fruit compared to ripe fruit. This result was corroborated by Ko (1986), who showed that unripe fruit present higher activity of peroxidases and polyphenol-oxidases compared to red fruit, but low levels of total phenolics, amino acids and carbohydrates. 

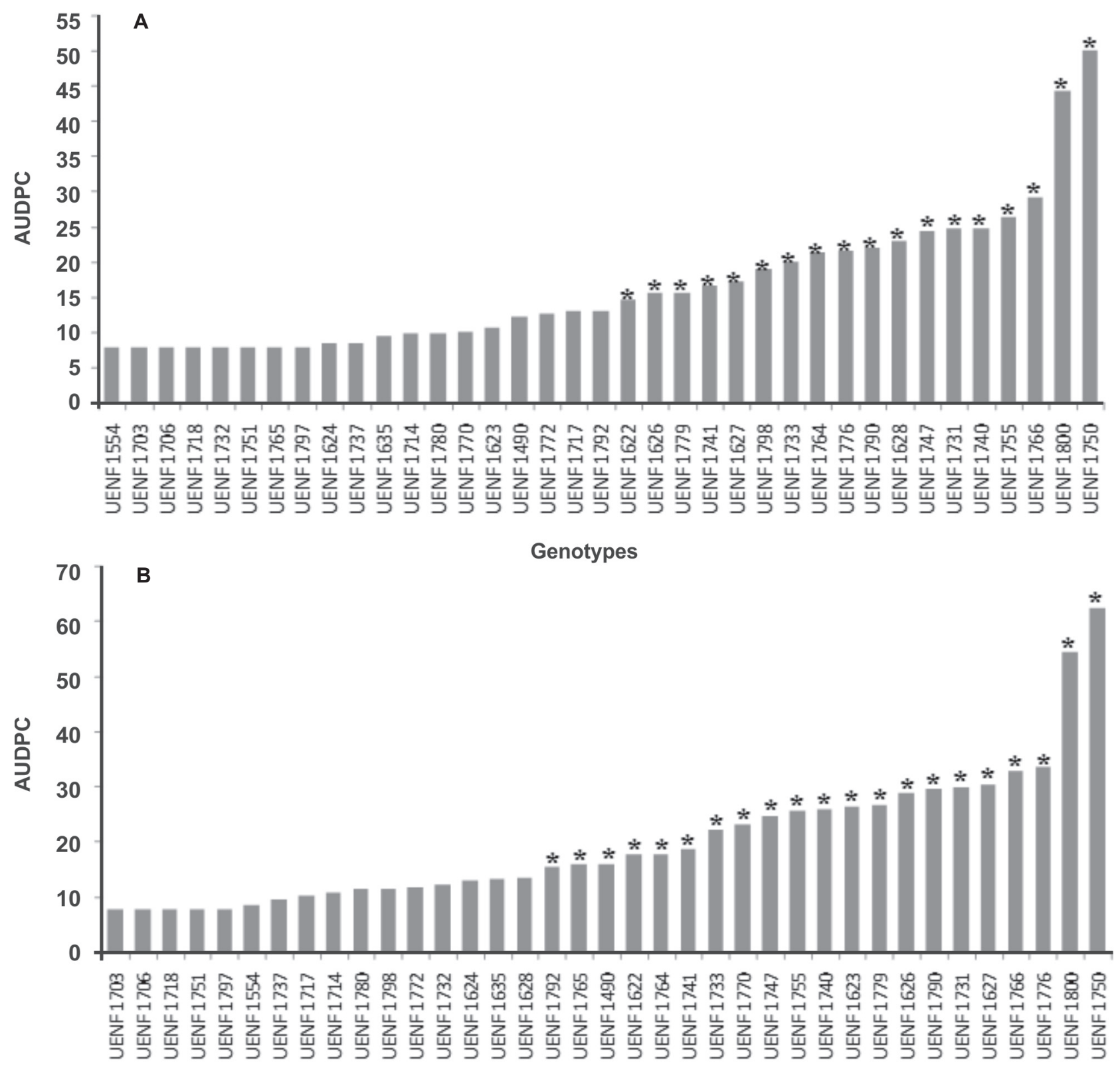

\section{Genotypes}

FIGURE 2 - Average values observed for the area under the disease progress curve (AUDPC) in ripe fruit in the plant (A) and detached (B) from 37 accessions of Capsicum spp. inoculated with Colletotrichum gloeosporioides. *, Significant differences of the accessions with no symptoms, in relation to the other accessions, at $5 \%$ probability by the Steel test.

Some sources of resistance to anthracnose in pepper have been reported in different countries, and sources of resistance are usually found in $C$. baccatum and C. chinense (Yoon 2003; Kim et al., 2008; Than et al., 2008a; Mahasuk et al., 2009ab). Park et al. (2009) suggested that $C$. baccatum has higher levels of resistance to anthracnose than other species of Capsicum, and that this species is an important source of genetic resources for resistance to anthracnose. However, according to Mahasuk et al. (2009a), resistant accessions of $C$. chinense are most commonly used in breeding programs aiming at resistance to anthracnose because this species belongs to the same gene pool as C. annuum, which indicates a greater chance of success in the transfer of resistance genes among species. However, successful crosses were carried out between C. annuum and C. baccatum to transfer the gene Bs 7 , which confers resistance to bacterial spot in sweet pepper (Potnis et al., 2012), demonstrating that gene transfer between these two species is possible. The accessions UENF 1718 and UENF 1797 belonging to C. baccatum var. pendulum are promising for introduction in breeding programs. 
TABLE 2 - Spearman's correlation between two variables (area under the disease progress curve - AUDPC and severity) for anthracnose in fruit from 37 accessions of Capsicum spp. at different stages, attached in the plant or detached and evaluated in the laboratory.

\begin{tabular}{|c|c|c|c|c|c|c|c|c|c|}
\hline \multicolumn{2}{|c|}{ Variables } & \multicolumn{2}{|c|}{ UFP $^{1}$} & \multicolumn{2}{|c|}{ UFL } & \multicolumn{2}{|c|}{ RFP } & \multicolumn{2}{|c|}{ RFL } \\
\hline & & AUDPC & Score & AUDPC & Score & AUDPC & Score & AUDPC & Score \\
\hline \multirow[t]{2}{*}{ UFP } & AUDPC & 1.00 & & & & & & & \\
\hline & Score & 0.98 & 1.00 & & & & & & \\
\hline \multirow[t]{2}{*}{ UFL } & AUDPC & 0.62 & 0.59 & 1.00 & & & & & \\
\hline & Score & 0.60 & 0.59 & 0.93 & 1.00 & & & & \\
\hline \multirow[t]{2}{*}{ RFP } & AUDPC & 0.11 & 0.06 & 0.52 & 0.45 & 1.00 & & & \\
\hline & Score & 0.22 & 0.20 & 0.55 & 0.60 & 0.89 & 1.00 & & \\
\hline \multirow[t]{2}{*}{$\overline{R F L}$} & AUDPC & 0.18 & 0.13 & 0.53 & 0.53 & 0.77 & 0.77 & 1.00 & \\
\hline & Score & 0.33 & 0.30 & 0.63 & 0.70 & 0.66 & 0.79 & 0.87 & 1.00 \\
\hline
\end{tabular}

'UFP, unripe fruit inoculated in the plant; UFL, unripe fruit detached and evaluated in laboratory; RFP, ripe fruit inoculated in the plant; RFL, ripe fruit detached and evaluated in laboratory.

\section{ACKNOWLEDGMENTS}

The authors are grateful for financial support received from Fundação Carlos Chagas Filho de Amparo à Pesquisa do Estado do Rio de Janeiro - FAPERJ and Coordenação de Aperfeiçoamento de Pessoal de Nível Superior - CAPES.

\section{REFERENCES}

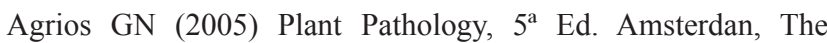
Netherlands. Academic Press.

Babu BS, Pandravada SR, Prasada-Rao RDVJ, Anitha K, Chakrabarty SK, Varaprasad KS (2011) Global sources of pepper genetic resources against arthropods, nematodes and pathogens. Crop Protection 30:389-400.

Bento CS, Rodrigues R, Zerbini FM, Sudré CP (2009) Sources of resistance against the Pepper yellow mosaic virus in chili pepper. Horticultura Brasileira 27: 96-201.

Bento CS, Sudré CP, Rodrigues R, Riva EM, Pereira MG (2007) Descritores qualitativos e multicategóricos na estimativa da variabilidade fenotípica entre acessos de pimentas. Scientia Agraria 8:146-153.

Campbell CL, Madden LV (1990) Introduction to Plant Disease Epidemiology. New York NY, USA. John Wiley \& Sons.

Kanchana-udomkan C, Taylor PWJ, Mongkolporn O (2004) Development of a biossay to study anthracnose infection of Capsicum chinense Jacq. fruit caused by Colletrotricum capsici. Thai Journal of Agricultural Science 37:293-7.

Kim KD, Oh BJ, Yang J (1999) Differential interactions of a Colletotrichum gloerosporioides isolate with green and red pepper fruit. Phytoparasitica 27:97-106.

Kim SH, Yoon JB, Do JW, Park HG (2008) A major recessive gene associated with anthracnose resistance to Colletotrichum capsici in chilli pepper (Capsicum annuum L.). Breeding Science 58:137141.

Kim KH, Yoon JB, Park HG, Park EW, Kim YH (2004) Structural modifications and programmed cell death of chili pepper fruit related to resistance responses to Colletotrichum gloeosporioides infection. Phytopathology 94:1295-1304.

Ko YH (1986) The physiological and biochemical characteristics of Colletotrichum gloeosporioides Penz. and the host plant, Capsicum annuum L. Ph.D. Dissertation, Korea University. Seoul, South Korea.

Lin Q, Kanchana-Udomkan C, Jaunet T, Mongkolporn O (2002) Genetic analysis of resistance to pepper anthracnose caused by Colletotrichum capsici. Thailand Journal of Agricultural Science 35:259-264.

Mahasuk P, Khumpeng N, Wasee S, Taylor PWJ, Mongkolporn O (2009a) Inheritance of resistance to anthracnose (Colletotrichum capsici) at seedling and fruiting stages in chili pepper (Capsicum spp.). Plant Breeding 128:701-706.

Mahasuk P, Taylor PWJ, Mongkolporn O (2009b) Identification of two new genes conferring resistance to Colletotrichum acutatum in Capsicum baccatum. Phytopathology 99:1100-1104.

Mongkolporn O, Montri P, Supakaew T, Taylor PWJ (2010) Differential reactions on mature green and ripe chili fruit infected by three Colletotrichum spp. Plant Disease 94:306-310.

Montri P, Taylor PWJ, Mongkolporn O (2009) Pathotypes of Colletotrichum capsici, the causal agent of chili anthracnose, in Thailand. Plant Disease 93:17-20.

Pakdeevaraporn P, Wasee S, Taylor PWJ, Mongkolporn O (2005) Inheritance of resistance to anthracnose caused by Colletotrichum capsici in Capsicum. Plant Breeding 124:206-208.

Park HK, Kim BS, Lee WS (1990a) Inheritance of resistance to anthracnose (Colletotrichum spp.) in pepper (Capsicum annuum L.). I. Genetic analysis of anthracnose resistance by diallel crosses. Journal of the Korean Society for Horticultural Science 31:91-105.

Park HK, Kim BS, Lee WS (1990b) Inheritance to resistance to anthracnose (Colletotrichum spp.) in pepper (Capsicum annuum L.). II. Genetic analysis of resistance to Colletotrichum dematium. Journal of the Korean Society for Horticultural Science 31:207212.

Park S, Kim SH, Park HG, Yoon JB (2009) Capsicum germplasm resistant to pepper anthracnose differentially interact with Colletotrichum isolates. Horticulture Environment Biotechnology 50:17-23.

Park S, Jeong WY, Lee JH, Kim YH, Jeong SW, Kim GS, Bae DW, Lim CS, Jin JS, Lee SJ, Shin SC (2012) Determination of polyphenol levels variation in Capsicum annuum L. cv. chelsea (yellow bell pepper) infected by anthracnose (Colletotrichum 
gloeosporioides) using liquid chromatography-tandem mass spectrometry. Food Chemistry 130:981-985.

Pereira MJZ, Massola Júnior NS, Sussel AAB, Sala FC, Costa CP, Boiteux LS (2011) Reação de acessos de Capsicum e de progênies de cruzamentos interespecíficos a isolados de Colletotrichum acutatum. Horticultura Brasileira 29:569-576.

Potnis N, Minsavage G, Hurlbert JC, Norman D, Rodrigues R, Stall RE, Jones JB (2012) Avirulence proteins AvrBs 7 from Xanthomonas gardneri and AvrBs1.1 from Xanthomonas euvesicatoria contribute to a novel gene-for-gene interaction in pepper. Molecular Plant-Microbe Interactions 25:307-320.

Sudré CP, Rodrigues R, Riva EM, Karasawa M, Amaral-Júnior AT (2005) Divergência genética entre acessos de pimenta e pimentão utilizando técnicas multivariadas. Horticultura Brasileira 23:2227.

Taylor PWJ, Mongkolporn O, Than PP, Montri P, Ranathunge N, Kanchana-Udonkan C, Ford R, Pongsupasamit S, Hyde KD (2007) Pathotypes of Colletotrichum spp. infecting chili peppers and mechanisms of resistance. In: Oh DG, Kim KT (Eds.) First International Symposium on Chilli Anthracnose, Abstracts... Seoul, South Korea. National Horticultural Research Institute. p. 29.
Than PP, Jeewon R, Hyde KD, Pongsupasamit S, Mongkolporn O, Taylor PWJ (2008a) Characterization and pathogenicity of Colletotrichum species associated with anthracnose on chili (Capsicum spp.) in Thailand. Plant Pathology 57:562-572.

Than PP, Prihastuti H, Phoulivong S, Taylor PWJ, Hyde KD (2008b) Chili anthracnose disease caused by Colletotrichum species. Journal of Zhejiang University Science B 9:764-778.

Voorrips RE, Finkers R, Sanjaya L, Groenwold R (2004) QTL mapping of anthracnose (Colletotrichum spp.) resistance in a cross between Capsicum annuum and C. chinense. Theoretical and Applied Genetics 109:1275-1282.

Yoon JB (2003) Identification of genetic resource, interspecific hybridization and inheritance analysis for breeding pepper (Capsicum annuum) resistant to anthracnose. Ph.D. Thesis, Seoul National University. Seoul, South Korea.

Yoon JB, Park HG (2005) Trispecies bridge crosses, (Capsicum annuum $\times C$. chinense $) \times C$. baccatum, as an alternative for introgression of anthracnose resistance from $C$. baccatum into $C$. annuum. Journal of the Korean Society for Horticultural Science 46:5-9.

TPP-2013-0149

Submitted: 26 August 2013

Revisions requested: 14 January 2014

Accepted: 14 February 2014

Section Editor: Nilceu R.X. Nazareno 